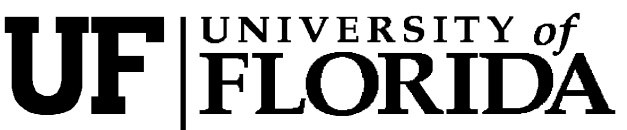 \\ IFAS Extension
}

SS AGR 277

\section{Effect of Southern Chinch Bug on Weed Establishment in St. Augustinegrass 1}

\section{Curtis Rainbolt, Ronald Cherry and Russell Nagata ${ }^{2}$}

\section{Introduction}

Interactions between weeds and arthropods can result in habitat modification that favors the development of one or both groups. In southern Florida, weed infestations commonly occur in St. Augustinegrass lawns infested with southern chinch bug, Blissus insularis Barber (Figure 1).

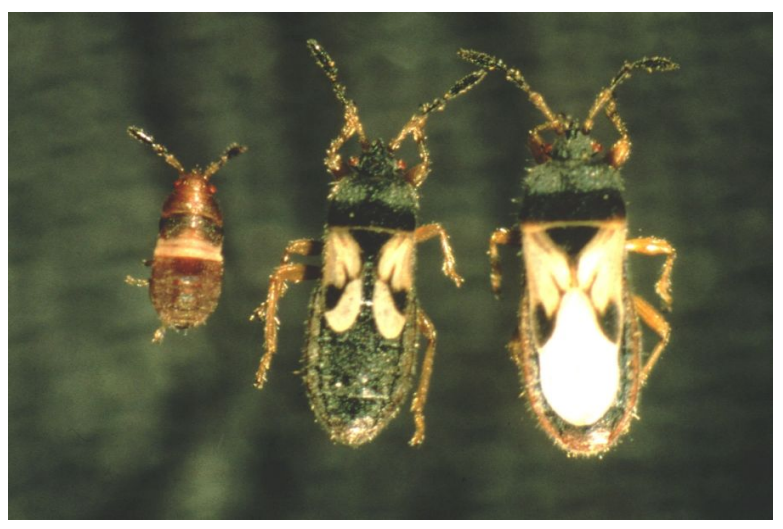

Figure 1.

The southern chinch bug is the most damaging insect pest of St. Augustinegrass (Figure 2), and it has the ability to develop resistance to insecticides and overcome host plant resistance. Heavy southern

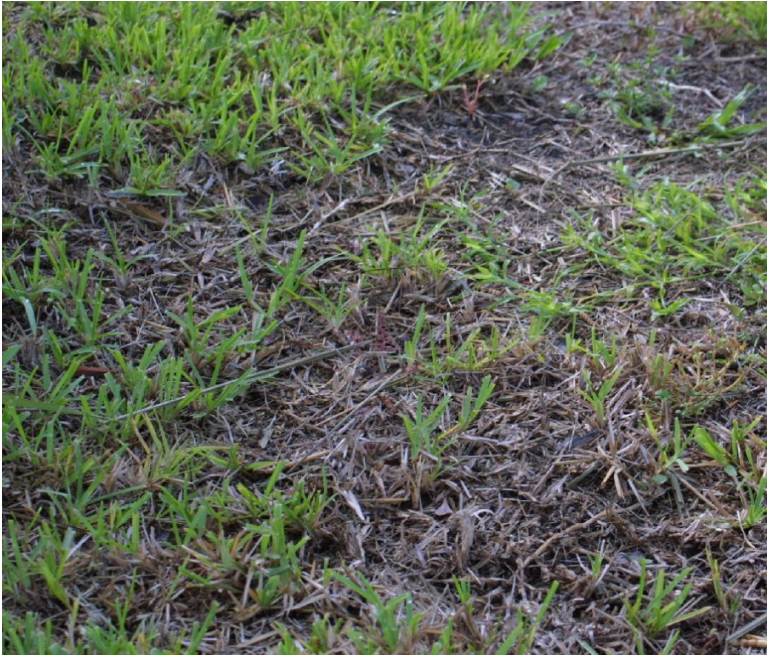

Figure 2.

chinch bug infestations have been shown to cause substantial damage to St. Augustinegrass that leads to dead, brown patches of turf. High turfgrass densities can prevent weeds from becoming established by occupying space, utilizing water and nutrients, and intercepting light. Vigorous and actively growing lawns are more able to compete with weeds than weakened or slow-growing lawns. Thus, conditions that weaken grass stands, such as damage from

1. This document is SS AGR 277, one of a series of the Agronomy Department, Florida Cooperative Extension Service, Institute of Food and Agricultural Sciences, University of Florida. Original publication date October 2007. Visit the EDIS Web Site at http://edis.ifas.ufl.edu.

2. Curtis Rainbolt, assistant professor, Agronomy Department, Everglades Research and Education Center--Belle Glade, FL; Ronald Cherry, professor, Entomology and Nematology Department; Russell Nagata, associate professor, Everglades Research and Education Center--Belle Glade, FL; Florida Cooperative Extension Service, Institute of Food and Agricultural Sciences, University of Florida, Gainesville, FL 32611.

The Institute of Food and Agricultural Sciences (IFAS) is an Equal Opportunity Institution authorized to provide research, educational information and other services only to individuals and institutions that function with non-discrimination with respect to race, creed, color, religion, age, disability, sex, sexual orientation, marital status, national origin, political opinions or affiliations. U.S. Department of Agriculture, Cooperative Extension Service, University of Florida, IFAS, Florida A. \& M. University Cooperative Extension Program, and Boards of County Commissioners Cooperating. Larry Arrington, Dean 
southern chinch bugs, can also result in increased weed populations (Figure 3).

\section{Research and Results}

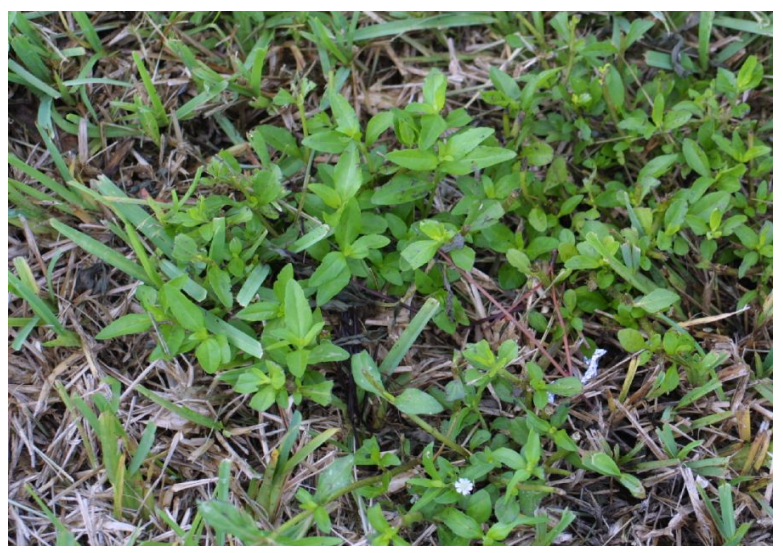

Figure 3.

In order to further understand the relationship between southern chinch bugs and weeds, experiments were conducted in urban St.

Augustinegrass lawns in southern Florida. Within each lawn site, southern chinch bug and weed populations were evaluated in three habitats in St. Augustinegrass. These habitats were healthy with few weeds, highly weedy, and damaged by active southern chinch bug infestations.

It is generally accepted that weeds can become a greater problem in crops that are damaged or weakened. In our experiment, weed populations were 6.8 X higher in the southern chinch bug infested St. Augustinegrass compared to the healthy St. Augustinegrass (Table 1). Additionally, St. Augustinegrass groundcover was less in weedy and chinch bug infested habitats than in the healthy St. Augustinegrass. When damage to a stand of turfgrass reduces groundcover, resources such as space and light become available to other plants (weeds) that are not being damaged. Healthy sites contained a mean of 3.8 different weed species compared to 6.8 in both weedy and southern chinch bug infested habitats. The most common weed species found in the study were alligatorweed (Alternanthera philoxeroides Mart.), livid amaranth (Amaranthus lividus L.), hairy beggarticks (Bidens alba (L.) DC.), Hyssop spurge (Chamaesyce hyssopifolia L. Small), common dayflower (Commelina diffusa Burm. f.), common bermudagrass (Cynodon dactylon (L.)
Pers.), yellow nutsedge (Cyperus esculentus L.), southern crabgrass (Digitaria ciliaris (Retz.) Koel.), green killinga, (Kyllinga brevifolia Rottb.), Florida pusley (Richardia scabra L.), and Florida yellow woodsorrel (Oxalis florida Salisb.). However, there were no trends indicating that certain weed species were more able than others to capitalize on southern chinch bug damage and become established. At most sites, the prevailing weed species in the healthy St. Augustinegrass habitat tended to be the dominant species in the neighboring infested and weedy habitats.

An average of 1957, 13, and 1 southern chinch bugs per $\mathrm{m}^{2}$ were found in the chinch bug infested, weedy, and healthy St. Augustinegrass, respectively. These data are consistent with previous research that showed similar southern chinch bug densities in St Augustinegrass and that southern chinch bugs are highly aggregated at infestations with few in surrounding healthy St. Augustinegrass. Superimposing chinch bug and weed data showed that weeds were infesting areas of chinch bug damage rather than that chinch bugs were attracted to weedy habitats.

\section{Summary}

The data from our study illustrate that southern chinch bug damage to St. Augustinegrass provides an opportunity for weeds to become established. Also, even after southern chinch bug infestations are reduced through insecticidal and/or natural controls, the weed problem at infestation sites remains. Consequently, weed suppression is an additional benefit that should be considered when determining the economic threshold for southern chinch bug control in St. Augustinegrass. 
Table 1.

\begin{tabular}{|c|c|c|c|}
\hline \multicolumn{4}{|c|}{ ground cover by habitat in St. Augustinegrass lawns". } \\
\hline & SCB & Weeds & Groundcover \\
\hline Habitat & per $\mathbf{m}^{2}$ & per $m^{2}$ & $\%$ \\
\hline SCB infested & $1957 \mathrm{~B}$ & $62 \mathrm{~B}$ & $39 \mathrm{~B}$ \\
\hline Highly weedy & $13 \mathrm{~A}$ & $165 \mathrm{~A}$ & $13 \mathrm{~A}$ \\
\hline Healthy & $1 \mathrm{~A}$ & $9 \mathrm{C}$ & $96 \mathrm{C}$ \\
\hline
\end{tabular}

